\title{
Effect of Homocysteine on Survival of Human Glial Cells
}

\author{
H. ŠKOVIEROVÁ ${ }^{1 *}$, S. MAHMOOD ${ }^{1}$, E. BLAHOVCOVÁ ${ }^{1}$, J. HATOK ${ }^{1}$, J. LEHOTSKÝ ${ }^{1}$, \\ R. MURÍN ${ }^{*}$ \\ ${ }^{*}$ These authors contributed equally to this work.
}

${ }^{1}$ Department of Medical Biochemistry, Jessenius Faculty of Medicine in Martin, Comenius University in Bratislava, Martin, Slovakia

Received August 20, 2014

Accepted December 12, 2014

On-line March 24, 2015

\begin{abstract}
Summary
Several neurodegenerative conditions, such as Alzheimer's disease and Parkinson's disease, or vascular dementia and cognitive impairment, are associated with mild hyperhomocysteinemia. Hyperhomocysteinemia is defined as an increase of the homocysteine (Hcy) level beyond $10 \mu \mathrm{M}$. Although the adverse effect of Hcy on neurons is well documented, knowledge about the impact of this amino acid on glial cells is missing. Therefore, with the aim to evaluate the neurotoxic properties of Hcy on glial cells, we used a glioblastoma cell line as a study model. The viability of cells was assayed biochemically and cytologically. At a concentration around $50 \mu \mathrm{M}$ in the culture medium D,L-Hcy induced cell death. It is noteworthy that Hcy induces cell death of human glial cells at concentrations encountered during mild hyperhomocysteinemia. Therefore, we propose that Hcy-induced impairment of neuronal functions along with damage of glial cells may contribute to the etiopathogenesis of neurodegenerative diseases associated with hyperhomocysteinemia.
\end{abstract}

\section{Key words}

Glioblastoma • Gliotoxicity • Homocysteine • Hyperhomocysteinemia

- Cell death $\bullet$ Neurodegeneration

\section{Corresponding author}

R. Murín, Comenius University in Bratislava, Jessenius Faculty of Medicine in Martin, Department of Medical Biochemistry, Mala hora 4, 03601 Martin, Slovakia. E-mail: murin@jfmed.uniba.sk

\section{Introduction}

Hyperhomocysteinemia is a condition characterized by an elevation of the concentration of L-homocysteine (Hcy) in plasma above its physiological level, which varies in range between 5-15 $\mu \mathrm{M}$ (mean $10 \mu \mathrm{M}$; Kang et al. 1992). Even mild hyperhomocysteinemia is considered as a risk factor for several neurodegenerative diseases (Mattson and Shea 2003, Neeman et al. 2005, Sachdev 2005, Herrmann and Obeid 2011), such as Alzheimer's (Clarke et al. 1998) and Parkinson's diseases (Allain et al. 1995, Kuhn et al. 1998), dementias (Gottfries et al. 1998, Seshadri et al. 2002), and brain atrophy (den Heijer et al. 2003, Sachdev et al. 2002). Under these conditions the amount of Hcy in blood, serum and cerebrospinal fluid reaches a range of concentrations in the tens of micromolar. The mechanism by which Hcy may exert its effects on brain cells is not fully understood (Obeid and Herrmann 2006). An early theory on the role of Hcy in neurodegeneration suggested an indirect effect of Hcy on brain tissue mediated via its capability to affect the properties of blood vessels and therefore to influence the exchange of compounds between blood stream and brain parenchyma. Several recent studies performed on cultured neural cells revealed that Hcy can also directly influence neural cells by several distinct mechanisms (Obeid and Herrmann 2006). Hcy is considered to exert an excitotoxic influence on neurons due to its role as a glutamate agonist acting on both the ionotropic (Olney et al. 1987, Lipton et al. 1997) and the metabotropic (Folbergrova et al. 2001, Zieminska et al. 2003, Lazarewicz et al. 2003) type of glutamate receptor, with an effect on intracellular calcium signaling. In addition, Hcy enhances formation of free radicals (Welch et al. 1997) and promotes oxidative stress (Streck 
et al. 2003).

Glial cells are the most numerous cellular constituent of brain parenchyma. They are heavily involved in sustaining physiological roles of this tissue (Allen and Barres 2009). In addition, they are considered to play an active role in the etiopathogenesis of neurodegenerative diseases (Vila et al. 2001, Teismann et al. 2003, Rodríguez et al. 2009). While the neurotoxic effect of Hcy on neuronal cells has been studied intensively, only a few data exists concerning its effect on glia. It has been shown that at millimolar concentration this amino acid impacts the survival of cultured rat astroglial cells (Maler et al. 2003). This concentration exceeds by more than one order of magnitude its estimated levels in elderly with progressing neurodegenerative disease. When applied to cultured rat astrocytes in micromolar concentrations Hcy compromises their metabolism (Jin and Brennan 2008), and induces cytoskeletal remodeling, oxidative stress (Loureiro et al. 2010) and epigenetic reprogramming (Jin et al. 2011). In spite of the knowledge that Hcy exerts effects on rat glial cells, the vulnerability of human glia remains enigmatic. Therefore, the present study was undertaken to mimic hyperhomocysteinemia in vitro to evaluate the hypothesis that Hcy may affect the viability of human glial cells.

\section{Materials and Methods}

\section{Materials}

Dulbecco's modified Eagle's medium (DMEM), fetal bovine serum (FBS), penicillin/streptomycin (P/S) solution, and trypsin/EDTA solution were from PAA (Pasching, Austria). D,L-Homocysteine, 3-[4,5dimethylthiazol-2-yl]-2,5-diphenyltetrazolium bromide (MTT), sodium dodecyl sulfate (SDS), propidium iodide (PI), and paraformaldehyde were purchased from Sigma (Bratislava, Slovakia). Dulbecco's phosphate buffer saline (DPBS, without $\mathrm{Ca}^{2+}$ and $\mathrm{Mg}^{2+}$ ) was from GibcoInvitrogen (Bratislava, Slovakia). VECTASHIELD mounting medium supplemented with 4',6-diamidino-2phenylindole (DAPI) were from Vector Laboratories (Peterborough, UK). Sterile plastic material and culture dishes for cell culture were from Greiner (Frickenhausen, Germany).

\section{Cell culture}

The human glioblastoma cell line T98G (ECACC, Sigma, Bratislava, Slovakia) was cultivated in culture medium consisting of DMEM supplemented with $10 \%$ (v/v) FBS, 100 I.U. penicillin per $\mathrm{ml}$ and $0.1 \mathrm{mg}$ streptomycin per $\mathrm{ml}$ in a humidified atmosphere with $10 \% \mathrm{CO}_{2}$ at $37^{\circ} \mathrm{C}$. The culture medium was renewed every third day.

\section{MTT assay}

The colorimetric MTT assay, based on the enzymatic conversion of MTT to a violet formazan salt (Mosmann 1983), was used to assess the viability of the T98G cells. The cells in culture medium were seeded in wells $\left(3 \times 10^{3} /\right.$ well $)$ of 96 -well microtiter plates. On the third day, the medium was changed to culture medium supplemented with Hcy of varied concentration and the incubation continued for the next two days. After treatment with $\mathrm{Hcy}$, the cells were rinsed once with DPBS (2.7 mmol. $\mathrm{l}^{-1} \mathrm{KCl} ; 1.5 \mathrm{mmol}^{-1} \mathrm{KH}_{2} \mathrm{PO}_{4}$; 138 mmol. $1^{-1} \mathrm{NaCl} ; 8.1 \mathrm{mmol} . \mathrm{l}^{-1} \mathrm{Na}_{2} \mathrm{HPO}_{4}$ ) and further incubated in medium supplemented with $0.5 \mathrm{mg} / \mathrm{ml}$ MTT in humidified atmosphere for $6 \mathrm{~h}$. During a subsequent incubation for $16 \mathrm{~h}$ in medium containing SDS [5\% $(\mathrm{w} / \mathrm{v})]$ the precipitated formazan, the amount of which is proportional to the number of live cells, was solubilized. The absorbance of the formazan containing solution was measured at $540 \mathrm{~nm}$ using an ELISA plate reader (BioRad PR2100). The absorbance was also determined for the medium of the control cells not exposed to Hcy and the corresponding viability was set as $100 \%$.

\section{Confocal microscopy}

For confocal laser scanning microscopy, $3 \times 10^{4}$ cells were grown on coverslips $(15 \mathrm{~mm} \times 15 \mathrm{~mm})$ in a 6-well plate (well diameter: $3 \mathrm{~cm}$ ). After 3 days, the medium was changed to culture medium supplemented with Hcy and cells were incubated as described in Cell culture for another 3 days. Two kinds of treatments were applied to stain the cells for fluorescent microscopic investigation. The cells were (i) washed by DPBS and subsequently fixed with ice cold methanol at room temperature for $5 \mathrm{~min}$ or (ii) incubated at $37^{\circ} \mathrm{C}$ in culture medium supplemented with PI $(0.75 \mu \mathrm{g} / \mathrm{ml})$ for $30 \mathrm{~min}$ before washing with DPBS and subsequent fixation with $4 \%(\mathrm{w} / \mathrm{v})$ paraformaldehyde for $10 \mathrm{~min}$. Fixed cells were washed twice with DPBS and once with DPBS supplemented with $0.1 \%$ (w/v) glycine. Cover slips were mounted cells down with Mounting medium supplemented with DAPI and the cells were examined on a confocal fluorescence microscope (Olympus FluoView FV10i, Tokyo, Japan). The blue fluorescence of DAPI 
was observed after excitation with wavelength of $359 \mathrm{~nm}$ and emission at $461 \mathrm{~nm}$ and red fluorescence of PI was inspected at wavelength excitation and emission of $537 \mathrm{~nm}$ and $617 \mathrm{~nm}$, respectively. The cell viability (\%) was assessed as the ratio between the numbers of cells staining positively for PI and the number of nuclei staining for DAPI in an area of $0.16 \mathrm{~mm}^{2}$.

\section{Statistical analysis}

One-way analysis of variance with post-hoc comparisons by Student-Newman-Keuls test was carried out to test for differences among groups. Differences between data sets were considered statistically significant if the corresponding $p$ values were $<0.05$. The statistical analysis was performed with the program InStat (GraphPad Software, USA).
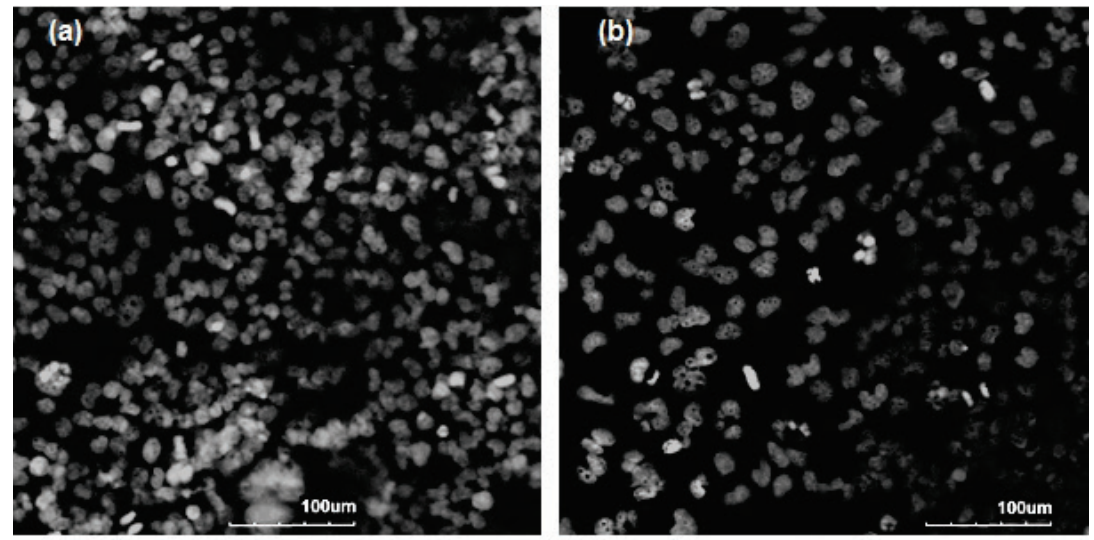

Fig. 1. Homocysteine affects the population size of cultures of human glioblastoma cells. T98G glioblastoma cells were grown in culture media without (a) or with D,L-Hcy [0.5 mM (b), $2 \mathrm{mM}$ (c), and $5 \mathrm{mM}$ (d)] for 3 days. Cells fixed by methanol had their nuclei stained with DAPI before they were inspected with a confocal laser scanning microscope.
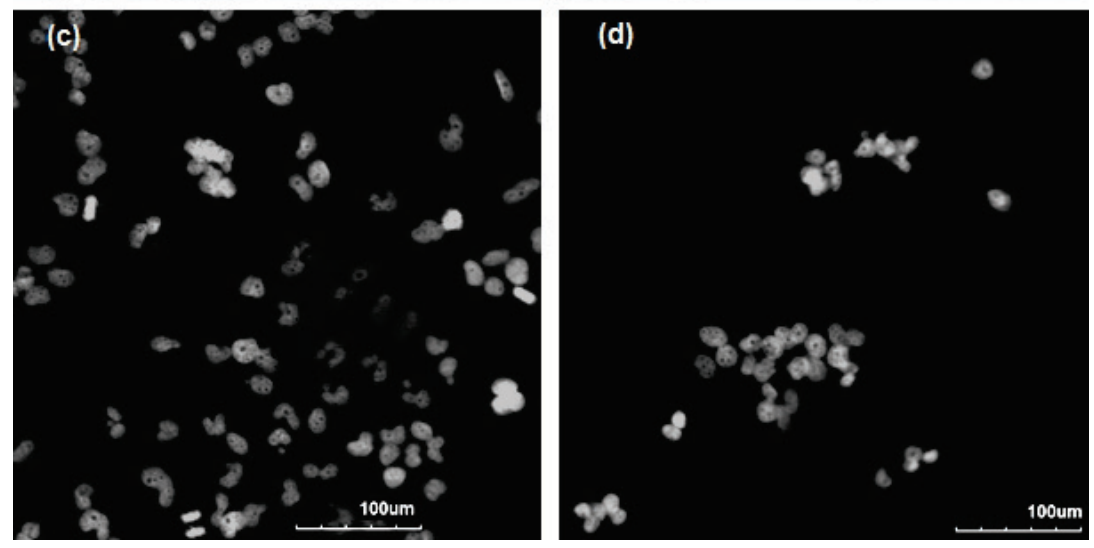

\section{Results}

\section{Hcy affects growth of cells}

An earlier study demonstrated that Hcy at a concentration of $2 \mathrm{mM}$ induced cell death in rat astrocytes (Maler et al. 2003). The Hcy concentrations chosen in the present study are in the range used in other in vitro studies (Jin and Brennan 2008). Glioblastoma cells were cultured with Hcy (0.5 mM, $2 \mathrm{mM}$, and $5 \mathrm{mM})$ for $72 \mathrm{~h}$. Nuclei were labeled with DAPI and visualized under the confocal microscope (Fig. 1). Cultures treated with Hcy at a concentration of $0.5 \mathrm{mM}$ (Fig. 1b) contained approximately $40 \%$ less cells than the untreated controls (Fig. 2i). At an Hcy concentration of $5 \mathrm{mM}$ (Fig. 1d) the cell number dropped to $25 \%$ of the control values (Fig. 2i).

\section{Hcy induced cell death}

In order to determine the influence of Hcy on the viability of the cells, glioblastoma cells were cultured in the presence of Hcy at various concentrations for $72 \mathrm{~h}$. For the visualization of dead cells the cultures were exposed to PI for $30 \mathrm{~min}$. This reagent penetrates dead cells due to their compromised plasma membranes but not alive cells with intact membranes. To assess the total number of cells the nuclei of fixed cells were stained with DAPI for inspection by confocal microscopy (Fig. 2). Based on the results obtained from staining with DAPI, in comparison to control cultures (Fig. 2a) the number of cells had decreased by $20 \%$, more than $40 \%$, and $75 \%$ during treatment with Hcy at concentrations of $50 \mu \mathrm{M}$ (Fig. 2c), $0.5 \mathrm{mM}$ (Fig. 2e) and $5 \mathrm{mM}$ (Fig. 2g), respectively. 

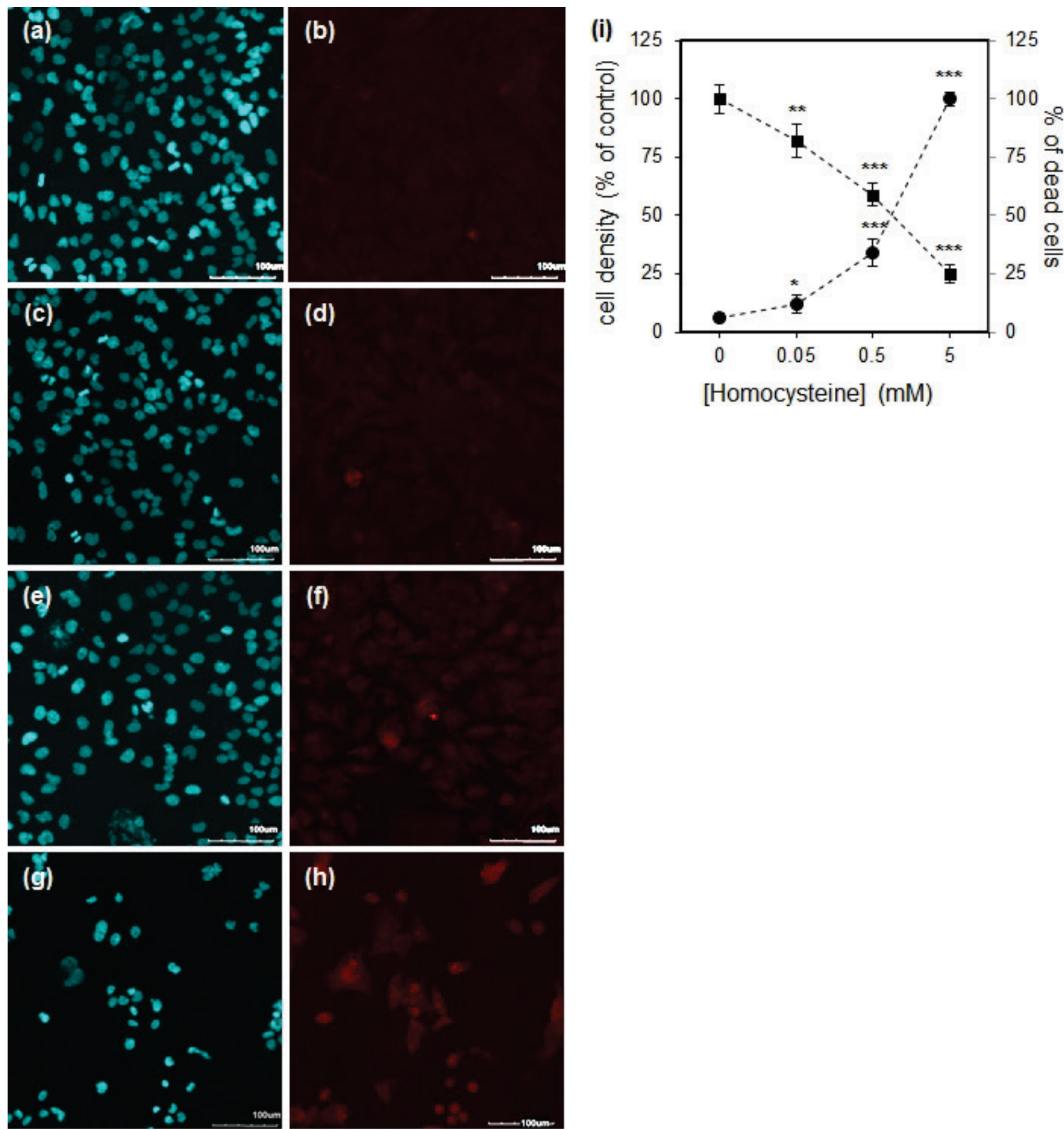

Fig. 2. Homocysteine-induced death of cultured human glioblastoma cells. Confocal laser scanning micrographs of T98G cells after incubation in media supplemented with $\mathrm{D}, \mathrm{L}-\mathrm{Hcy}$ (c and $\mathbf{d}, 50 \mu \mathrm{M}$; e and $\mathbf{f}, 0.5 \mathrm{mM} ; \mathbf{g}$ and $\mathbf{h}, 5 \mathrm{mM}$;) for 3 days. The control cells were cultivated in the same medium without addition of $\operatorname{Hcy}(\mathbf{a}, \mathbf{b})$. The dead cells were labeled by PI $(\mathbf{b}, \mathbf{d}, \mathbf{f}$, and $\mathbf{h})$ added to the culture media for the last $30 \mathrm{~min}$ of the culture time. After fixation of cells by paraformaldehyde the nuclei were visualized by the intercalating fluorescent dye DAPI ( $\mathbf{a}, \mathbf{c}, \mathbf{e}$, and $\mathbf{g})$. CTR, control cells without addition of Hcy. Changes in both, cell density ( $\mathbf{(})$ and percentage of dead cells in culture $(\bullet)$ were determined (i). The results are the average of the mean values \pm SD from three independent experiments $(\mathrm{n}=15) . * p<0.05 ; * * p<0.001 ; * * * p<0.005$

With increasing concentrations of Hcy the proportion of cells labeled with PI increases (Fig. 2i). In control cultures not treated with Hcy only a few cells were labeled by PI (Fig. 2b). The cultures exposed to Hcy at concentrations of $50 \mu \mathrm{M}$ (Fig. 2d), $0.5 \mathrm{mM}$ (Fig. 2f) and $5 \mathrm{mM}$ (Fig. 2h) contain 2, 6, and almost 17 times, respectively, more PI labeled cells than the controls. The estimated values of dead cells (Fig. 2i) might be grossly underestimated as a consequence of probable detachment of the dead cells from the surface. This result indicates that the extent of cell death increases with the concentration of Hcy in the culture medium. 


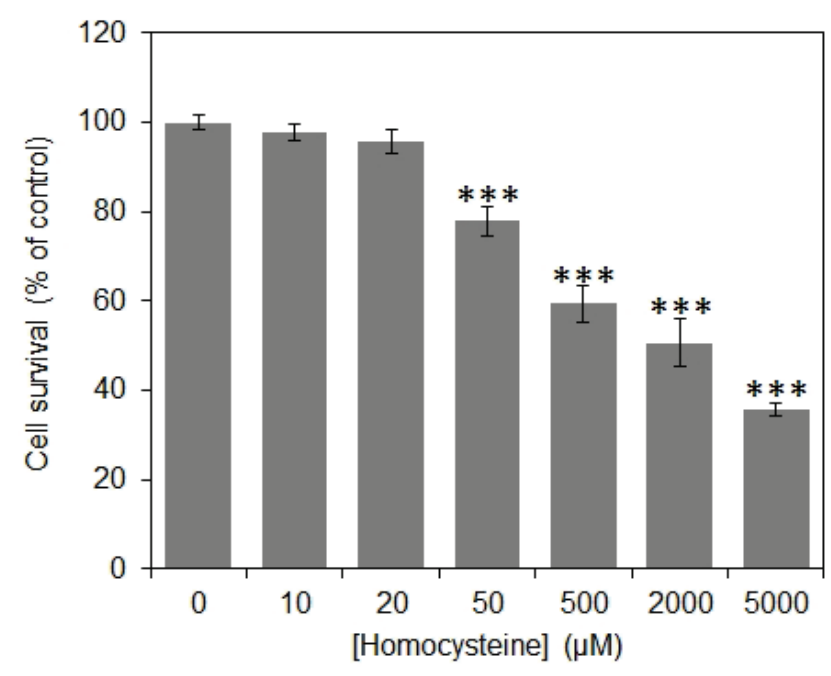

Fig. 3. Effect of homocysteine on the MTT-assessed viability of cultured human glioblastoma cells. For 2 days the cells of human glioblastoma cell line T98G were grown in microtiter plates in culture medium supplemented with D,L-Hcy of varied concentration. Thereafter, the viability of the cells was assessed by the MTT assay described in the Methods section. The amount of the ensuing MTT-formazan was determined spectrophotometrically at $540 \mathrm{~nm}$. The control value (100\% viability) was determined with cells that had been incubated in culture medium in which no homocysteine had been added to. The results are the average of a mean \pm SEM values from three independent experiments $(\mathrm{n}=18)$. $* * * \quad p<0.005$

\section{Effect of Hcy on cell viability}

After exposure of glioblastoma cells to Hcy $(10 \mu \mathrm{M}$ to $5 \mathrm{mM})$ for $48 \mathrm{~h}$ their viability was measured by a colorimetric method, the MTT assay. Already at a concentration of $50 \mu \mathrm{M} \mathrm{D}, \mathrm{L}-\mathrm{Hcy}$, corresponding to $25 \mu \mathrm{M}$ of the physiological enantiomer L-Hcy (Poddar et al. 2001) caused a statistically significant decrease in viability to $78 \%$. This effect was even stronger at $2 \mathrm{mM}$ (50\% viability) and $5 \mathrm{mM}$ D,L-Hcy (36\% viability; Fig. 3).

\section{Discussion}

Evidence is provided that D,L-Hcy in concentrations above $50 \mu \mathrm{M}$ induces the death of cultured human glioblastoma cells. The cell line T98G used in this study was derived from human glioblastoma cells (Stein 1979) and together with other cell lines such as A172 and U-87MG (De Vries and Boullerne 2010) derived from glioblastoma and astrocytoma, respectively, represents a valuable tool to investigate the properties of human astrocytes in culture.

A plasma Hcy concentration around $10 \mu \mathrm{M}$ is considered to be physiological, while mild and moderate hyperhomocysteinemia are the conditions when the concentration of L-homocysteine in the plasma are in the ranges from $10-30$ or $30-100 \mu \mathrm{M}$, respectively. Severe forms of hyperhomocysteinemia, usually associated with the deficiency in the enzymes metabolizing homocysteine, are characterized by the level of homocysteine in plasma exceeding $100 \mu \mathrm{M}$ (Kang et al. 1992, Mansoor et al. 1993). During neurodegenerative conditions, such as Alzheimer's disease, the levels of homocysteine in serum and cerebrospinal fluid are both increased above the normal value to a mean value above $20 \mu \mathrm{M}$ (Selley et al. 2002). The present publication reports on the effects on the viability of T98G cells of Hcy at concentrations ranging from physiological levels to levels found under severe hyperhomocysteinemia.

Previous investigations had shown that Hcy has a detrimental influence on human neurons (Ho et al. 2002, Lipton et al. 1997, Oldreive and Doherty 2007), whereas cultured rat astroglial cells sustain Hcy up to concentrations of $2 \mathrm{mM}$ (Maler et al. 2003). The results presented here reveal that in contrast to rat glial cells the human glioblastoma cells of the present study undergo cell death already at D,L-Hcy concentrations in culture medium of $50 \mu \mathrm{M}$. Since only the $\mathrm{L}$ enantiomer is biologically active (Poddar et al. 2001) and occurs naturally (Ueland and Refsum 1989) this corresponds to a concentration of $25 \mu \mathrm{M}$ of the $\mathrm{L}$ enantiomer of Hcy. Such concentration is comparable with the level of L-Hcy determined in the cerebrospinal fluid of patients with Alzheimer's disease (Selley et al. 2002). Thus, the data presented here demonstrate that Hcy is a potent gliotoxic agent capable of inducing the death of human glial cells already at concentrations reached in brain during hyperhomocysteinemia (Selley et al. 2002).

L-Hcy is a non-proteinogenic amino acid containing a sulfhydryl group. In the cells, Hcy is generated by hydrolysis of $S$-adenosylhomocysteine, which is a byproduct of transmethylation processes in which $S$-adenosylmethionine serves as a methyl donor. In the mammalian body Hcy may be enzymatically or spontaneously converted to a number of compounds. Enzymatic conversions lead to compounds such as methionine, cystathionine, homocystine, and homocysteine-thiolactone (Jakubowski 2004). The data available suggest that Hcy, even at moderate levels, can exert its neurotoxic effect by i) several mechanisms that trigger neuronal cell death, e.g., increased oxidative stress (Imamura et al. 2007); ii) acting as an agonist for glutamate receptors; iii) its capability to elicit a rise in the 
level of cytosolic $\mathrm{Ca}^{2+}$ (Olney et al. 1987, Lipton et al. 1997, Folbergrova et al. 2001, Zieminska et al. 2003, Lazarewicz et al. 2003); and iv) inducing DNA damage and changes in energy metabolism associated with reduced availability of ATP (Kruman et al. 2002). In rat astrocytes Hcy i) significantly modulates metabolism by affecting the mitochondrial functions (Jin and Brennan 2008); and ii) causes epigenetic modifications by hypomethylation of global DNA and hyperacetylation of histones (Jin et al. 2011).

The increase in the level of Hcy accompanies the progression of several neurodegenerative diseases (Mattson and Shea 2003, Sachdev 2005, Herrmann and Obeid 2011). It is well known that Hcy acts as a neurotoxin by exerting several adverse effects on neurons (Mattson and Shea 2003). Nevertheless, the precise molecular mechanism(s) underling its roles in the etiopathogenesis of neurodegenerative diseases remain to be fully elucidated. Furthermore, the capability of Hcy to induce the death of cultured human glioblastoma cells indicates its gliotoxicity. Therefore, an increase in the Hcy level in the brain may also cause a decline in physiological functions of glia and a progression of neurodegeneration (Rodríguez and Verkhratsky 2011). In accordance with these pieces of knowledge the present results support the view that damage of both, neuronal and glial cells, may underlie the etiopathogeneses of the neurodegenerative diseases associated with hyperhomocysteinemia.

\section{Conflict of Interest}

There is no conflict of interest.

\section{Acknowledgements}

The authors are grateful to Mária Kovalská, Daniel Čierny and Stanislav Straka for their highly engaged laboratory work. R. M. also wishes to thank Bernd Hamprecht and Brigitte Pfeiffer-Guglielmi (University of Tuebingen, Germany) as well as Ralf Dringen (University of Bremen) for their valuable discussions and comments. This work was financially supported from the projects: VEGA 1/0242/13 and APVV-0224-12 and cofinanced from EU sources and the European Regional Development Fund Identification of novel markers in diagnostic panel of neurological diseases (code: 26220220114), Competence center for research and development in diagnosis and therapy (code: 26220220153), and The increasing of opportunities for career growth in research and development in the medical sciences (code 26110230067).

\section{References}

ALlAin P, LE BOUIL A, CORDILlET E, LE QUAY L, BAGHERI H, MONTASTRUC JL: Sulfate and cysteine levels in the plasma of patients with Parkinson's disease. Neurotoxicology 16: 527-529, 1995.

ALLEN NJ, BARRES BA: Neuroscience: Glia - more than just brain glue. Nature 457: 675-677, 2009.

CLARKE R, SMITH AD, JOBST KA, REFSUM H, SUTTON L, UELAND PM: Folate, vitamin B12, and serum total homocysteine levels in confirmed Alzheimer disease. Arch Neurol 55: 1449-1455, 1998.

DE VRIES GH, BOULLERNE AI: Glial cell lines: an overview. Neurochem Res 35: 1978-2000, 2010.

DEN HEIJER T, VERMEER SE, CLARKE R, OUDKERK M, KOUDSTAAL PJ, HOFMAN A, BRETELER MM: Homocysteine and brain atrophy on MRI of non-demented elderly. Brain 126: 170-175, 2003.

FOLBERGROVÁ J, HAUGVICOVÁ R, MARES P: Attenuation of seizures induced by homocysteic acid in immature rats by metabotropic glutamate group II and group III receptor agonists. Brain Res 908: 120-129, 2001.

GOTTFRIES CG, LEHMANN W, REGLAND B: Early diagnosis of cognitive impairment in the elderly with the focus on Alzheimer's disease. J Neural Transm 105: 773-786, 1998.

HERRMANN W, OBEID R: Homocysteine: a biomarker in neurodegenerative diseases. Clin Chem Lab Med 49: 435$441,2011$.

HO PI, ORTIZ D, ROGERS E, SHEA TB: Multiple aspects of homocysteine neurotoxicity: glutamate excitotoxicity, kinase hyperactivation and DNA damage. J Neurosci Res 70: 694-702, 2002.

IMAMURA K, TAKESHIMA T, NAKASO K, NAKASHIMA K: Homocysteine is toxic for dopaminergic neurons in primary mesencephalic culture. Neuroreport 18: 1319-1322, 2007.

JAKUBOWSKI H: Molecular basis of homocysteine toxicity in humans. Cell Mol Life Sci 61: 470-487, 2004.

JIN Y, BRENNAN L: Effects of homocysteine on metabolic pathways in cultured astrocytes. Neurochem Int 52: 14101415, 2008. 
JIN Y, AMARAL A, MCCANN A, BRENNAN L: Homocysteine levels impact directly on epigenetic reprogramming in astrocytes. Neurochem Int 58: 833-838, 2011.

KANG SS, WONG PW, MALINOW MR: Hyperhomocyst(e)inemia as a risk factor for occlusive vascular disease. Annu Rev Nutr 12: 279-298, 1992.

KRUMAN II, KUMARAVEL TS, LOHANI A, PEDERSEN WA, CUTLER RG, KRUMAN Y, HAUGHEY N, LEE J, EVANS M, MATTSON MP: Folic acid deficiency and homocysteine impair DNA repair in hippocampal neurons and sensitize them to amyloid toxicity in experimental models of Alzheimer's disease. J Neurosci 22: 1752-1762, 2002.

KUHN W, ROEBROEK R, BLOM H, VAN OPPENRAAIJ D, MULLER T: Hyperhomocysteinaemia in Parkinson's disease. J Neurol 245: 811-812, 1998.

LAZAREWICZ JW, ZIEMBOWICZ A, MATYJA E, STAFIEJ A, ZIEMINSKA E: Homocysteine-evoked ${ }^{45}$ Ca release in the rabbit hippocampus is mediated by both NMDA and group I metabotropic glutamate receptors: in vivo microdialysis study. Neurochem Res 28: 259-269, 2003.

LIPTON SA, KIM WK, CHOI YB, KUMAR S, D'EMILIA DM, RAYUDU PV, ARNELLE DR, STAMLER JS: Neurotoxicity associated with dual actions of homocysteine at the N-methyl-D-aspartate receptor. Proc Natl Acad Sci U S A 94: 5923-5928, 1997.

LOUREIRO SO, ROMÃO L, ALVES T, FONSECA A, HEIMFARTH L, MOURA NETO V, WYSE AT, PESSOAPUREUR R: Homocysteine induces cytoskeletal remodeling and production of reactive oxygen species in cultured cortical astrocytes. Brain Res 1355: 151-164, 2010.

MALER JM, SEIFERT W, HÜTHER G, WILTFANG J, RÜTHER E, KORNHUBER J, BLEICH S: Homocysteine induces cell death of rat astrocytes in vitro. Neurosci Lett 347: 85-88, 2003.

MANSOOR MA, UELAND PM, AARSLAND A, SVARDAL AM: Redox status and protein binding of plasma homocysteine and other aminothiols in patients with homocystinuria. Metabolism 42: 1481-1485, 1993.

MATTSON MP, SHEA TB: Folate and homocysteine metabolism in neural plasticity and neurodegenerative disorders. Trends Neurosci 26: 137-146, 2003.

MOSMANN T: Rapid colorimetric assay for cellular growth and survival: application to proliferation and cytotoxicity assays. J Immunol Methods 65: 55-63, 1983.

NEEMAN G, BLANARU M, BLOCH B, KREMER I, ERMILOV M, JAVITT DC, HERESCO-LEVY U: Relation of plasma glycine, serine, and homocysteine levels to schizophrenia symptoms and medication type. $A m J$ Psychiatry 162: 1738-1740, 2005.

OBEID R, HERRMANN W: Mechanisms of homocysteine neurotoxicity in neurodegenerative diseases with special reference to dementia. FEBS Lett 580: 2994-3005, 2006.

OLDREIVE CE, DOHERTY GH: Neurotoxic effects of homocysteine on cerebellar Purkinje neurons in vitro. Neurosci Lett 413: 52-57, 2007.

OLNEY JW, PRICE MT, SALLES KS, LABRUYERE J, RYERSON R, MAHAN K, FRIERDICH G, SAMSON L: L-homocysteic acid: an endogenous excitotoxic ligand of the NMDA receptor. Brain Res Bull 19: 597-602, 1987.

PODDAR R, SIVASUBRAMANIAN N, DIBELLO PM, ROBINSON K, JACOBSEN DW: Homocysteine induces expression and secretion of monocyte chemoattractant protein-1 and interleukin-8 in human aortic endothelial cells: implications for vascular disease. Circulation 103: 2717-2723, 2001.

RODRÍGUEZ JJ, VERKHRATSKY A: Neuroglial roots of neurodegenerative diseases? Mol Neurobiol 43: 87-96, 2011.

RODRÍGUEZ JJ, OLABARRIA M, CHVATAL A, VERKHRATSKY A: Astroglia in dementia and Alzheimer's disease. Cell Death Differ 16: 378-385, 2009.

SACHDEV PS: Homocysteine and brain atrophy. Prog Neuropsychopharmacol Biol Psychiatry 29: 1152-1161, 2005.

SACHDEV PS, VALENZUELA M, WANG XL, LOOI JC, BRODATY H: Relationship between plasma homocysteine levels and brain atrophy in health elderly individuals. Neurology 58: 1539-1541, 2002.

SELLEY ML, CLOSE DR, STERN SE: The effect of increased concentrations of homocysteine on the concentration of (E)-4-hydroxy-2-nonenal in the plasma and cerebrospinal fluid of patients with Alzheimer's disease. Neurobiol Aging 23: 383-388, 2002. 
SESHADRI S, BEISER A, SELHUB J, JACQUES PF, ROSENBERG IH, D'AGOSTINO RB, WILSON PW, WOLF PA: Plasma homocysteine as a risk factor for dementia and Alzheimer's disease. $N$ Engl J Med 346: 476-483, 2002.

STEIN GH: T98G: an anchorage-independent human tumor cell line that exhibits stationary phase G1 arrest in vitro. J Cell Physiol 99: 43-54, 1979.

STRECK EL, VIEIRA PS, WANNMACHER CM, DUTRA-FILHO CS, WAJNER M, WYSE AT: In vitro effect of homocysteine on some parameters of oxidative stress in rat hippocampus. Metab Brain Dis 18: 147-154, 2003.

TEISMANN P, TIEU K, COHEN O, CHOI DK, WU DC, MARKS D, VILA M, JACKSON-LEWIS V, PRZEDBORSKI S: Pathogenic role of glial cells in Parkinson's disease. Mov Disord 18: 121-129, 2003.

UELAND PM, REFSUM H: Plasma homocysteine, a risk factor for vascular disease: plasma levels in health, disease, and drug therapy. J Lab Clin Med 114: 473-501, 1989.

VILA M, JACKSON-LEWIS V, GUÉGAN C, WU DC, TEISMANN P, CHOI DK, TIEU K, PRZEDBORSKI S: The role of glial cells in Parkinson's disease. Curr Opin Neurol 14: 483-489, 2001.

WELCH GN, UPCHURCH GR Jr, LOSCALZO J: Homocysteine, oxidative stress, and vascular disease. Hosp Pract (Minneap) 32: 81-82, 85, 88-92, 1997.

ZIEMIŃSKA E, STAFIEJ A, ŁAZAREWICZ JW: Role of group I metabotropic glutamate receptors and NMDA receptors in homocysteine-evoked acute neurodegeneration of cultured cerebellar granule neurones. Neurochem Int 43: 481-492, 2003. 